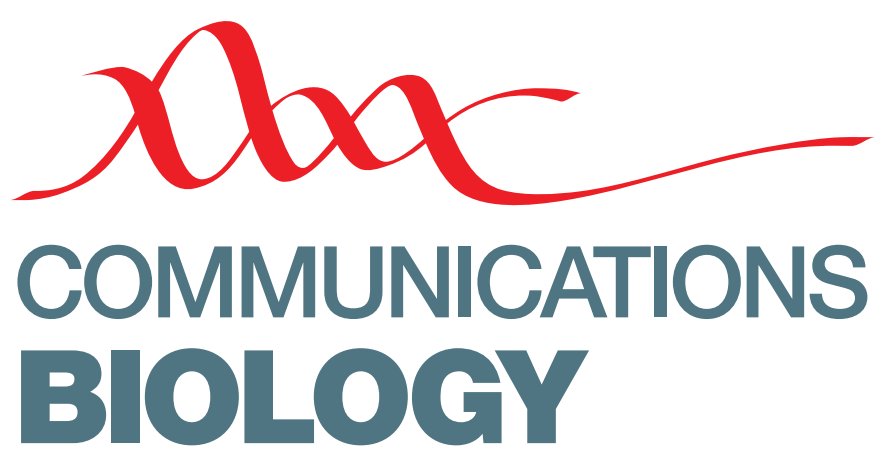

\title{
https://doi.org/10.1038/s42003-021-01680-7 OPEN
}

\section{Publisher Correction: A dopamine metabolite stabilizes neurotoxic amyloid- $\beta$ oligomers}

\author{
Rodrigo Cataldi(D), Sean Chia, Katarina Pisani, Francesco S. Ruggeri (1), Catherine K. Xu (1D, Tomas Šneideris (1D,
} Michele Perni $\mathbb{D}$, Sunehera Sarwat, Priyanka Joshi $\mathbb{D}$, Janet R. Kumita $\mathbb{D}$, Sara Linse, Johnny Habchi,

Tuomas P. J. Knowles (D), Benedetta Mannini (D), Christopher M. Dobson \& Michele Vendruscolo (B)

Correction to: Communications Biology https://doi.org/10.1038/s42003-020-01490-3, published online 4 January 2021.

In the original published Article there was an error in the labelling of the $\mathrm{X}$ axis for Fig. 5B, D and F. In all three cases A! should have appeared as $A \beta$ as correctly denoted in panel $A$.

Published online: 26 January 2021

\footnotetext{
(c) (i) Open Access This article is licensed under a Creative Commons Attribution 4.0 International License, which permits use, sharing, adaptation, distribution and reproduction in any medium or format, as long as you give appropriate credit to the original author(s) and the source, provide a link to the Creative Commons license, and indicate if changes were made. The images or other third party material in this article are included in the article's Creative Commons license, unless indicated otherwise in a credit line to the material. If material is not included in the article's Creative Commons license and your intended use is not permitted by statutory regulation or exceeds the permitted use, you will need to obtain permission directly from the copyright holder. To view a copy of this license, visit http://creativecommons.org/licenses/by/4.0/.
}

(c) The Author(s) 2021 